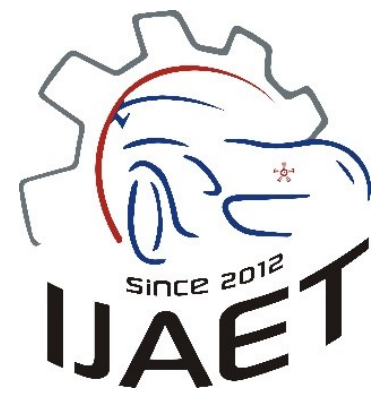

e-ISSN: 2146 - 9067

International Journal of Automotive

Engineering and Technologies

journal homepage:

https://dergipark.org.tr/en/pub/ijaet

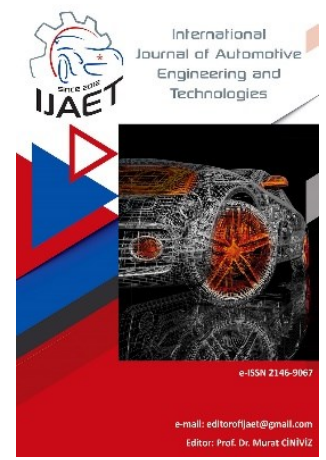

\title{
Analysis of the effects of cetane improver addition to diesel on engine performance and emissions
}

\author{
Süleyman Şimşek ${ }^{1}$, Samet Uslu ${ }^{2 *}$ \\ ${ }^{1}$ İstanbul Aydın Üniversitesi, Makine Mühendisliği Bölümü, İstanbul, Türkiye \\ ${ }^{2 *}$ Karabük Üniversitesi, Makine Mühendisliği Bölümü, Karabük, Türkiye
}

\section{ARTICLE INFO}

1. 0000-0002-0593-8036

2. $0000-0001-9118-5108$

Doi: $10.18245 /$ ijaet.798221

* Corresponding author sametuslu@karabuk.edu.tr

Received: Sept 21, 2020

Accepted: Feb 15, 2021

Published: Mar 31, 2021

Published by Editorial Board Members of IJAET

(C) This article is distributed by Turk Journal Park System under the CC 4.0 terms and conditions.

\begin{abstract}
The high cetane number of the fuel used in diesel engines is extremely important as it provides some improvements in combustion in the cylinder. Therefore, the addition of cetane improver to diesel fuel has been highly preferred in recent years. In this study, the effects of 2-ethylhexyl nitrate (EHN) addition, a cetane improver, on compression ignition engine performance and emissions were analyzed at various engine loads. Four different fuels were used in the experiments as $100 \%$ diesel (D100), 99\% diesel + 1\% EHN (D99EHN1), 98\% diesel + 2\% EHN (D99EHN2) and 97\% diesel + 3\% EHN (D99EHN3). The results obtained from the experiments showed that the addition of 2-EHN positively affected the brake thermal efficiency (BTHE), hydrocarbon (HC) and carbon monoxide $(\mathrm{CO})$ values, while the brake specific fuel consumption (BSFC), nitrogen oxide $\left(\mathrm{NO}_{\mathrm{x}}\right)$ and smoke emission levels were negatively affected. With high engine load, 2-EHN supplement marginally rises $\mathrm{NO}_{\mathrm{x}}$ emissions but significantly declines $\mathrm{HC}$ and $\mathrm{CO}$ emissions. EHN addition had small impacts on BSFC. Compared to D100 fuel, the highest BTHE value was obtained by D99EHN2 fuel, with an increase of $11.57 \%$ at 3000 -Watt load value. With the D97EHN3 fuel, compared to diesel, $\mathrm{HC}$ emission decreased $60.61 \%$, while CO emission decreased $31.25 \%$. The results show that the 2 -EHN cetane improver can be used successfully in a diesel engine.

Keywords: 2-ethylhexyl nitrate, cetane improver, diesel engine, performance, emission
\end{abstract}

\section{Introduction}

Nowadays, diesel engines are selected in many sectors due to their high economy, superior efficiency, and minimal fuel prices [1]-[3]. Diesel engines are one of the biggest consumers of fossil fuels in the world and emissions from these engines are one of the main suppliers of pollution in the environment [4]-[7]. With the environmental damage caused by the use of fossil fuels, insufficient reserves and the increase in demand for fossil fuel, the common perception worldwide is to find new fuels to reduce fossil fuel consumption or to minimize the negative effects of fossil fuel use [8]-[13]. Fuel additives have become interesting because biofuels are relatively costly to obtain and commercialize. The additives used in diesel engines are generally called cetane improvers. One of the main properties of diesel fuels is their cetane number which points out the ignition delay of the fuel in the process [14]. Therefore, 
additives that contribute to increase the cetane number of the fuel used are extremely important. Recently, various cetane improver additives such as alkyl-nitrates, 2-EHN and diethyl ether have been used in diesel engines to enhance the self-ignition quality of the fuel used [15]-[17]. Between the commonly employed cetane improver additives, 2-EHN is an industrial cetane improver, which presents the greatest performance in the most competitive way [18]. 2-EHN gives free radicals into the combustion space, accelerates oxidation activity, which enhances combustion attributes, and lowers flaming point and diminishes ignition delay [19]-[22]. The chemical formula is $\mathrm{C}_{8} \mathrm{H}_{17} \mathrm{NO}_{3}$, with the main structure an ethyl hexane molecule with one of the hydrogen atoms substituted with an $\mathrm{NO}_{3}$ nitrate radical [22], [23]. EHN is stable under room temperature situations and thus EHN only decomposes in the cylinder after injection and stays stable in the fuel injection system [24], [25]. Simsek and Uslu [15] formed a mixture of biodiesel obtained from different raw materials and added 2-EHN to this mixture and examined its effects. In addition, they applied RSM to determine the optimum $2-E H N$ ratio and biodiesel ratio at optimum engine load. They stated that the engine has ideal operation at $1515-\mathrm{W}$ load, with $100 \%$ biodiesel rate and $1.1 \%$ EHN rate. Pan et al. [26] investigated the effects by adding different proportions of EHN to dimethyl carbonate / diesel mixtures in a fourcylinder turbocharged diesel engine. They stated that the use of EHN improves the performance and on the other hand increases the fuel consumption. Kuszewski [27] studied the effect of 2-EHN addition on the autoignition properties of an ethanol-diesel fuel mixture with $15 \%$ ethanol content. According to his results, he stated that as the 2-EHN ratio in an ethanoldiesel fuel mixture increased, the ignition and burning delay times decreased.

Although there are many studies in the literature regarding the use of 2-EHN in combination with biodiesel or some kind of alcohol in diesel engines [28-29], there are limited studies on the use of diesel fuel [30]. From this point of view, it has been deemed appropriate to conduct a study on 2-EHN / diesel mixtures. The aim of this study is to combine 2-EHN cetane improver with diesel to achieve improvement in performance and emission responses. For this purpose, the effects of 2-EHN additive on the performance and emissions of a compression ignition engine were examined and the advantages and disadvantages compared to diesel fuel use were compared.

\section{Material and Method}

The tests were performed with a single cylinder low power diesel engine and using four various fuels at several engine load (500, 1000, 1500, 2000, 2500 and 3000-Watt) values. Four different fuels were used in the experiments: $100 \%$ diesel (D100), 99\% diesel + 1\% EHN (D99EHN1), 98\% diesel $+2 \%$ EHN (D99EHN2) and 97\% diesel $+3 \%$ EHN (D99EHN3). The fuel characteristics of diesel and 2-EHN used in the experiments were obtained by testing in the energy and chemistry laboratory of TÜBİTAK Marmara Research Center according to TS EN 14214 standard and are displayed in Table 1. The experimental setup used is displayed in Figure 1. The experimental setup includes diesel engine, dynamometer, emission analyzer, load unit, load control unit and fuel consumption measurement unit. The properties of engine are shown in Table 2.

Table 1. Fuel properties

\begin{tabular}{lll}
\hline & Diesel & 2-EHN \\
\hline Chemical Formula & $\mathrm{C}_{13} \mathrm{H}_{28}$ & $\mathrm{C}_{8} \mathrm{H}_{17} \mathrm{NO}_{3}$ \\
Oxygen Content (wt. \%) & 0 & 27.429 \\
Lower Calorific Value $(\mathrm{MJ} / \mathrm{kg})$ & 43.2 & 15.781 \\
$\begin{array}{l}\text { Density at } 15{ }^{\circ} \mathrm{C}\left(\mathrm{kg} / \mathrm{m}^{3}\right) \\
\text { Cetane Number }\end{array}$ & 883.6 & 963 \\
$\begin{array}{l}\text { Kinematic Viscosity at } 40{ }^{\circ} \mathrm{C} \\
\left(\mathrm{mm}^{2} / \mathrm{s}\right)\end{array}$ & 54 & $>76$ \\
\hline
\end{tabular}

Table 2. Properties of engine

\begin{tabular}{ll}
\hline Engine Properties & \\
\hline Type & Katana KM 178 FE \\
Maximum Horsepower & $6.7 \mathrm{hp}$ \\
Overall Volume & $296 \mathrm{~cm}^{3}$ \\
Engine Speed & $3000 \mathrm{rpm}$ \\
\hline Generator Properties & \\
\hline Brand & Katana \\
Power & $3.36 \mathrm{kVA}$ \\
Voltage & $230 \mathrm{~V}$ \\
Frequency & $50 \mathrm{~Hz}$ \\
Phases & 1 \\
\hline
\end{tabular}

\section{Result and Discussion}

In internal combustion engines, it is desirable that the BTHE be as high as possible, which is 


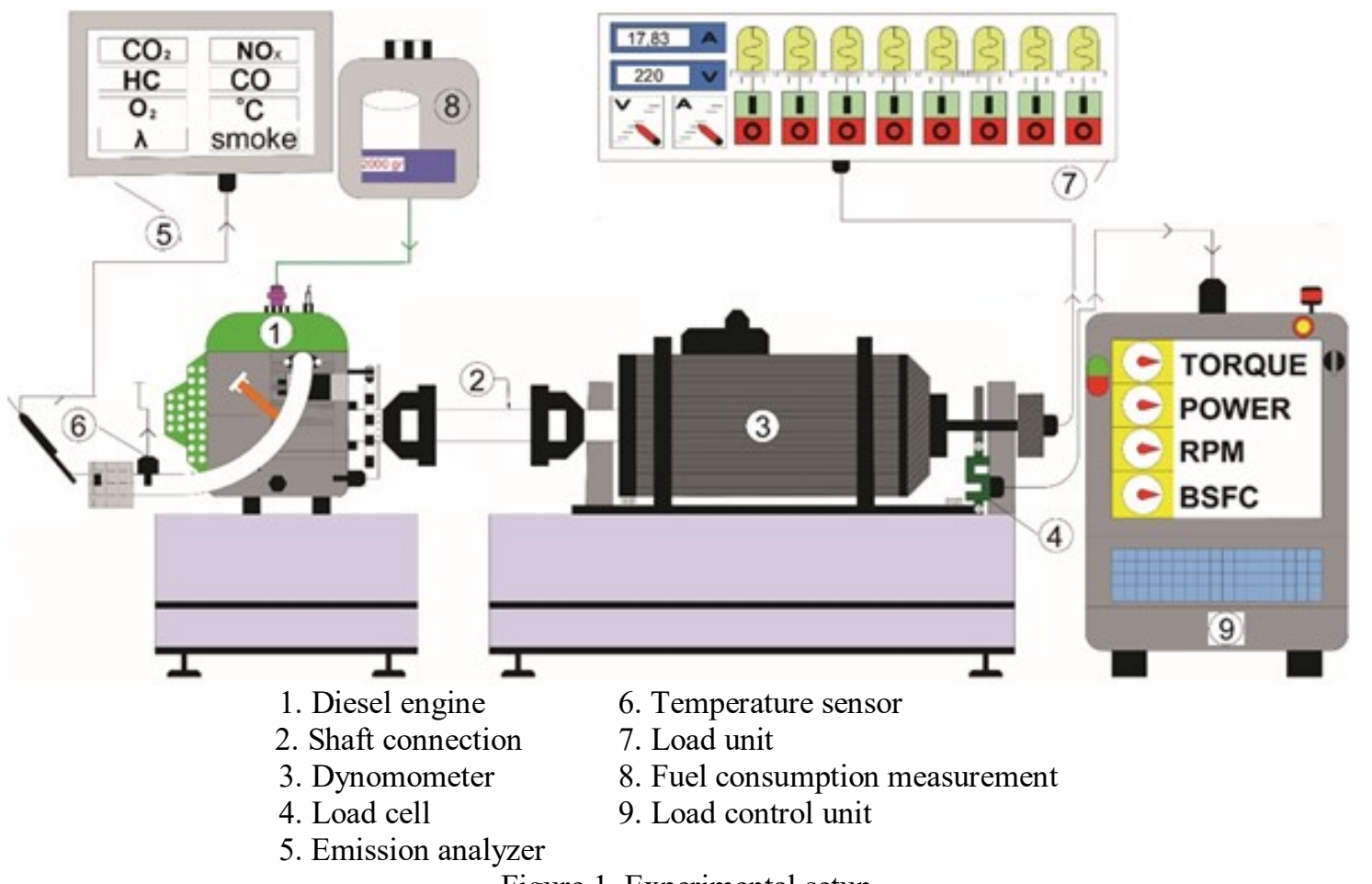

Figure 1. Experimental setup

an indicator of how much of the fuel supplied to the cylinder is beneficial. The cetane number is an expression of the ignition quality of a diesel fuel [31]. The ignition quality of the fuel with a high cetane number means it has a high ignition tendency. Therefore, high cetane number is a condition that improves the BTHE value. The variation of BTHE values obtained by using four different fuels with different engine loads is shown in Figure 2. It is clearly seen that BTHE increases with the use of 2-EHN. The maximum BTHE value was obtained with the addition of $2 \%$ 2-EHN, and with the addition rate of $3 \%$ BTHE tended to decrease. As the cetane number increases, the ignition delay decreases [32] and the BTHE increases. However, as the cetane number increases too much, the combustion rate increases, and the combustion is completed without shifting to the expansion period. This causes the BTHE to begin to decrease. The high cetane number shortens the ignition delay time while at the same time increasing

the burning rate. For this reason, the completion of the combustion without shifting to the expansion period decreased the BTHE value. Compared to D100 fuel, the highest BTHE value was achieved with D99EHN2 fuel, with an increase of $11.57 \%$ at 3000 -Watt load value. BSFC is described as the mass of fuel that the internal combustion engine must spend per hour to produce $1 \mathrm{~kW}$ of power [33]. BSFC is a parameter directly related to the lower calorific value of the fuel used [34]. When fuels with low calorific value are used, more fuel must be consumed in order to get the same power from the engine. Therefore, it is expected that the BSFC obtained with fuels with low lower calorific value will be high. Looking at Table 1, it is clear that the lower calorific value of $2-\mathrm{EHN}$ is quite low compared to diesel. As expected, when looking at Figure 3, the BSFC value increased with the use of 2-EHN. Maximum BSFC value was found to be $1057.5 \mathrm{~g} / \mathrm{kWh}$ at 500-Watt with D97EHN3 fuel. Compared to diesel, an increase of $8.47 \%$ was observed.

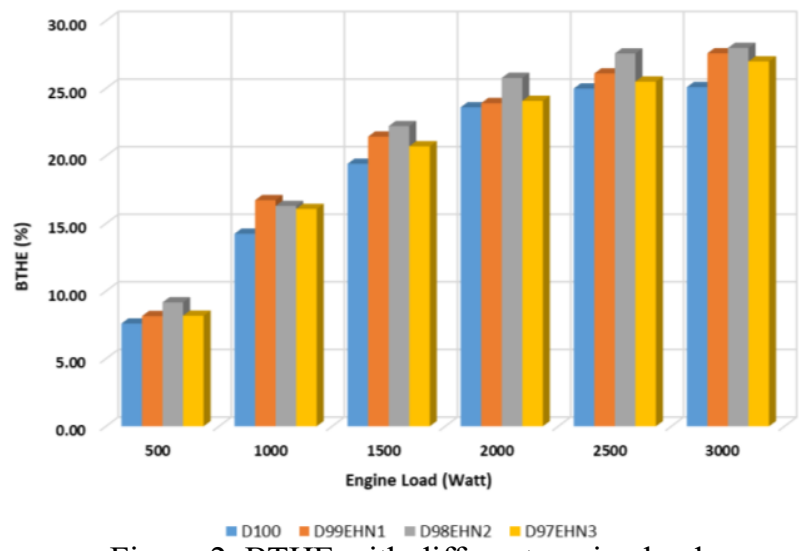

Figure 2. BTHE with different engine load

The main causes of $\mathrm{NO}_{\mathrm{x}}$ emissions are high temperature in the cylinder and the presence of nitrogen atoms [35]. At high temperatures and high nitrogen content in the cylinder, $\mathrm{NO}_{\mathrm{x}}$ is 
expected to increase. The presence of nitrogen atom in the content of 2-EHN, whose chemical formula is given in Table 1, is clearly seen.

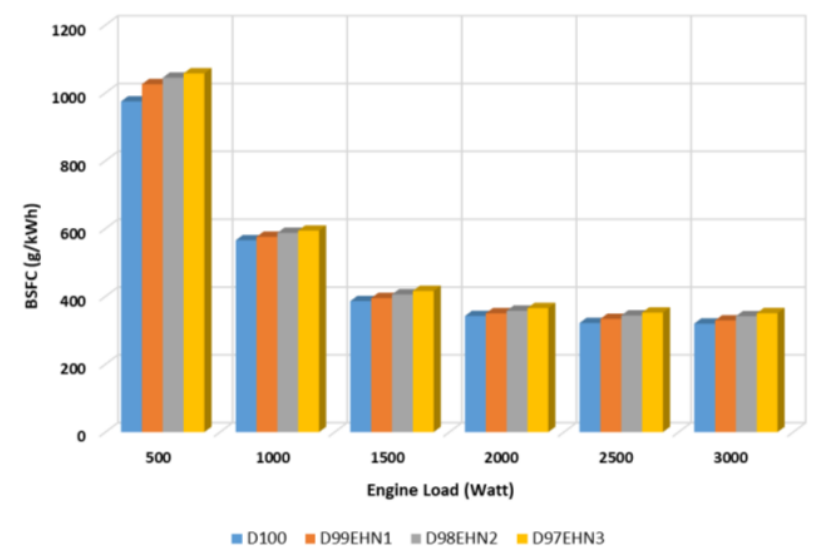

Figure 3. BSFC with different engine load

For this reason, as seen in Figure 4, it is thought that $\mathrm{NO}_{\mathrm{x}}$ emissions increase with the addition of 2-EHN. On the other hand, $\mathrm{NO}_{\mathrm{x}}$ emissions also increased as the increased engine load caused an increase in cylinder temperature. The maximum $\mathrm{NO}_{\mathrm{x}}$ was achieved with D97EHN3 test fuel at an engine load of $3000 \mathrm{~W}$. An increase as $42.68 \%$ was observed at the same engine load compared to the D100 fuel. Figure 5 shows the variation of smoke emissions depending on engine load. Smoke emissions are a type of emission that is adversely affected by the increasing cetane number. Therefore, increasing cetane number also increases smoke emissions. Since the cetane number of 2-EHN is higher than diesel, smoke emissions increased with the addition of 2-EHN. Figure 6 and Figure 7 show the variation of $\mathrm{HC}$ and $\mathrm{CO}$ emissions, respectively. Both $\mathrm{HC}$ and $\mathrm{CO}$ emissions are an incomplete combustion product [36]. Although there are many factors that cause incomplete combustion in internal combustion engines, the most effective one is insufficient oxygen [37]. For this reason, if there is enough oxygen in the cylinder, full combustion occurs and both $\mathrm{HC}$ and $\mathrm{CO}$ emissions decrease. When the fuel properties shown in Table 1 are examined, there is an oxygen mass of $27.429 \%$ in 2 -EHN. Therefore, with the use of 2-EHN, HC and CO emissions decreased and continued to decrease with growing 2-EHN. While CO emission tended to decrease up to $2000 \mathrm{~W}$ engine load, it tended to increase again due to the increase in engine load. While there was enough oxygen for the fuel sent to the cylinder at low engine loads, insufficient oxygen due to the excess fuel sent to the cylinder at increased engine load caused this situation. With the D97EHN3 fuel, compared to diesel, HC emission decreased $60.61 \%$, while $\mathrm{CO}$ emission decreased $31.25 \%$.

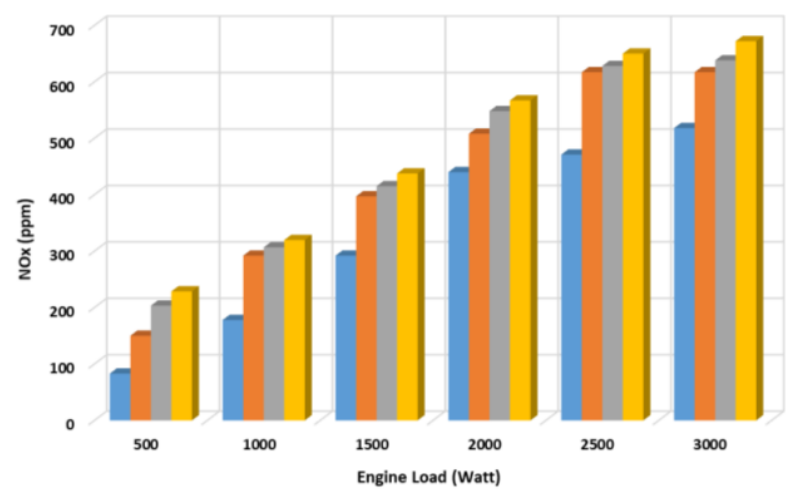

=D100 =D99EHN1 $=$ D98EHN2 =D97EHN3

Figure 4. $\mathrm{NO}_{\mathrm{x}}$ emission with different engine load

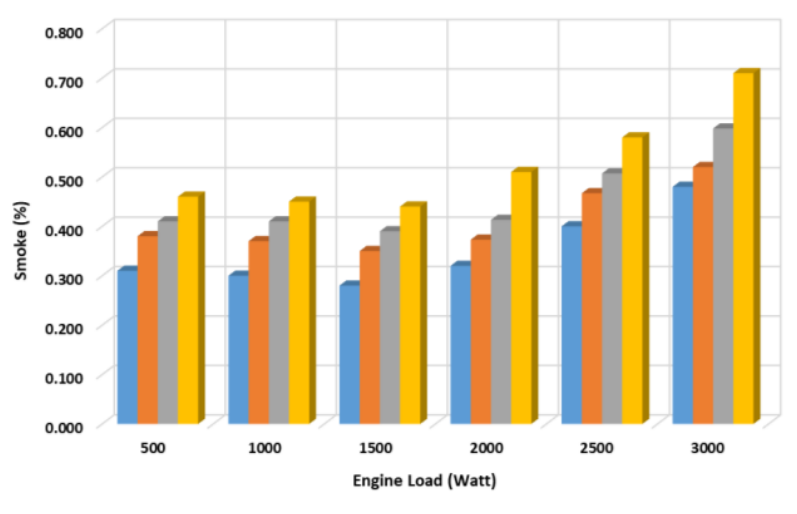

=D100 = D99EHN1 =D98EHN2 = D97EHN3

Figure 5. Smoke emission with different engine load

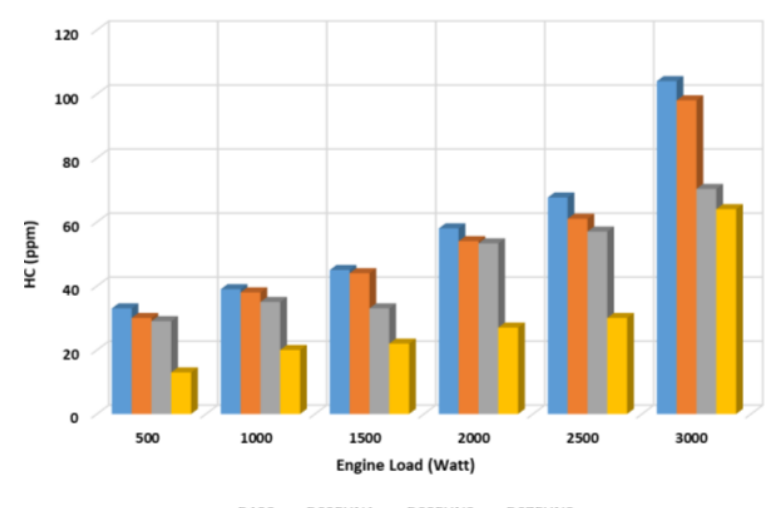

Figure 6. HC emission with different engine load

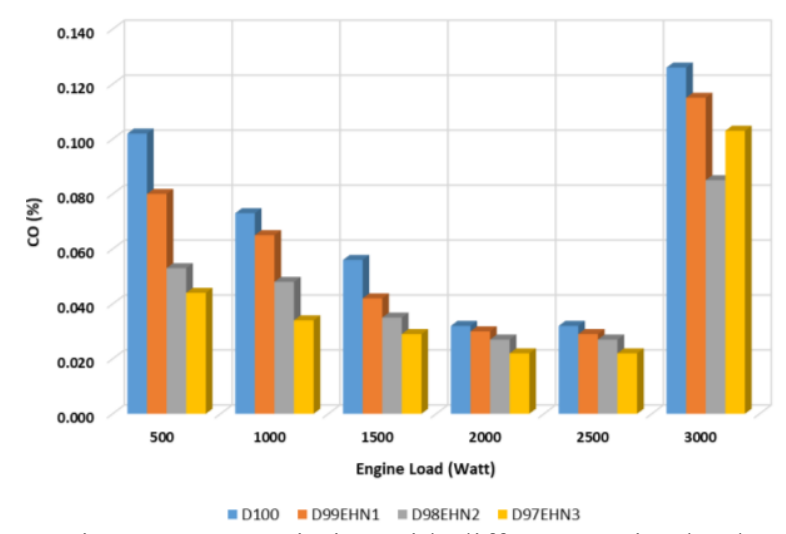

Figure 7. CO emission with different engine load 


\section{Conclusion}

In this study, the effects of adding 2-EHN to diesel fuel at different rates were investigated at different engine loads. The main results obtained at the end of the study are as follows;

$\checkmark$ The addition of 2-EHN up to $2 \%$ increased the BTHE values at all loads. Due to the very high cetane number, BTHE tended to decrease with the addition of 3\% 2EHN. The maximum BTHE value was achieved with D99EHN2 fuel as $27.99 \%$ at $3000 \mathrm{~W}$ load. An increase of $11.57 \%$ compared to D100 was observed at the same load.

$\checkmark$ BSFC values increased at all loads with the addition of 2-EHN. The lowest BSFC was obtained with D100 fuel at $3000 \mathrm{~W}$ load as $319.78 \mathrm{~g} / \mathrm{kWh}$.

$\checkmark \quad \mathrm{NO}_{\mathrm{x}}$ and smoke emissions increased with the addition of 2-EHN. The highest $\mathrm{NO}_{\mathrm{x}}$ and smoke emissions were obtained with D97EHN3 as $672 \mathrm{ppm}$ and $0.710 \%$, respectively.

$\checkmark \mathrm{HC}$ and $\mathrm{CO}$ emissions reduced with the use of 2-EHN. With the D97EHN3 fuel, compared to diesel, $\mathrm{HC}$ emission decreased $60.61 \%$, while CO emission decreased $31.25 \%$ compared to diesel at same load.

As a result, the use of 2-EHN increased $\mathrm{NO}_{\mathrm{x}}$, smoke and BSFC values, but reduced BTHE, $\mathrm{HC}$ and CO. It can be said that the use of 2-EHN as an additive in the diesel engine is successful, depending on the output requested from the engine.

\section{Nomenclature}

$\begin{array}{ll}\text { BSFC } & : \text { brake specific fuel consumption } \\ \text { BTHE } & : \text { brake thermal efficiency } \\ \text { CO } & : \text { carbon monoxide } \\ \text { D100 } & : 100 \% \text { diesel } \\ \begin{array}{l}\text { D99EHN1 } \\ \text { nitrate }\end{array} & : 99 \% \text { diesel }+1 \% \text { 2-ethylhexyl } \\ \begin{array}{l}\text { D98EHN2 } \\ \text { nitrate }\end{array} & : 98 \% \text { diesel }+2 \% \text { 2-ethylhexyl } \\ \begin{array}{l}\text { D97EHN3 } \\ \text { nitrate }\end{array} & : 97 \% \text { diesel }+3 \% \text { 2-ethylhexyl } \\ \text { EHN } & : \text { 2-ethylhexyl nitrate } \\ \text { HC } & : \text { hydrocarbon } \\ \text { NO }_{x} & : \text { nitrogen oxide }\end{array}$

\section{References}

1. Fayyazbakhsh, A. and Pirouzfar, V.,
"Investigating the influence of additives-fuel on diesel engine performance and emissions: Analytical modeling and experimental validation," Fuel, vol. 171, no. 167-177, 2016.

2. H. M. Goga, C., Chauhan, B. S., Mahla, S. K. and Cho, "Performance and emission characteristics of diesel engine fueled with rice bran biodiesel and n-butanol," Energy Reports, vol. 5, pp. 78-83, 2019.

3. Aydın, M., Uslu, S., Çelik, M. B., "Performance and emission prediction of a compression ignition engine fueled with biodiesel-diesel blends: A combined application of ANN and RSM based optimization," Fuel, vol. $269,2020$.

4. Mahlia, T.M.I., Syazmi, Z.A.H.S., Mofijur, M., Abas, A.E.P., Bilad, M.R., Ong, H.C., Silitonga, A.S., "Patent landscape review on biodiesel production: Technology updates," Renew. Sustain. Energy Rev., vol. 118, p. 109526, 2020.

5. S. Simsek, "Effects of biodiesel obtained from Canola, sefflower oils and waste oils on the engine performance and exhaust emissions," Fuel, vol. 265, p. 117026, 2020.

6. Abdollahi, M., Ghobadian, B., Najafi, G., Hoseini, S.S., Mofijur, M., Mazlan, M., "Impact of water - biodiesel - diesel nanoemulsion fuel on performance parameters and diesel engine emission," Fuel, vol. 280, p. 118576, 2020.

7. Şimşek, S., Saygın, H., Özdalyan, B., "Improvement of Fusel Oil Features and Effect of Its Use in Different Compression Ratios for an SI Engine on Performance and Emission," Energies, vol. 13, no. 7, p. 1824, 2020.

8. Uslu, S. and Celik, M. B., "Combustion and emission characteristics of isoamyl alcoholgasoline blends in spark ignition engine," Fuel, vol. 262, 2020.

9. L. Anantha Raman, B.Deepanraj, S.Rajakumar, and V.Sivasubramaniand, "Experimental investigation on performance, combustion and emission analysis of a direct injection diesel engine fuelled with rapeseed oil biodiesel," Fuel, vol. 246, pp. 69-74, 2019.

10. F. Yang, H. Cho, H. Zhang, J. Zhang, and $\mathrm{Y}$. Wu, "Artificial neural network (ANN) based prediction and optimization of an organic Rankine cycle (ORC) for diesel engine waste heat recovery," Energy Convers. Manag., vol. 164, no. February, pp. 15-26, 2018. 
11. S. Simsek, S. and Uslu, "Comparative evaluation of the influence of waste vegetable oil and waste animal oil-based biodiesel on diesel engine performance and emissions," Fuel, vol. 280, p. 118613, 2020.

12. Sun, C.S., Liu, Y., Qiao, X., Ju, D., Tang, Q., Fang, X., Zhou, F., "Experimental study of effects of exhaust gas recirculation on combustion, performance, and emissions of DME-biodiesel fueled engine," Energy, vol. 197, p. 1172333, 2020.

13. Simsek, S. and Uslu, S., "Determination of a diesel engine operating parameters powered with canola, safflower and waste vegetable oil based biodiesel combination using response surface methodology (RSM)," Fuel, vol. 270, 2020.

14. Noushabadi, A.S., Dashti, A., Raji, M., Zarei, A., Mohammadi, A.H., "Estimation of cetane numbers of biodiesel and diesel oils using regression and PSO-ANFIS models," Renew. Energy, vol. 158, pp. 465-473, 2020.

15. S. Simsek and S. Uslu, "Investigation of the effects of biodiesel/2-ethylhexyl nitrate (EHN) fuel blends on diesel engine performance and emissions by response surface methodology (RSM)," Fuel, vol. 275, p. 118005, Sep. 2020.

16. Uslu, S. and Aydin, M., "Effect of operating parameters on performance and emissions of a diesel engine fueled with ternary blends of palm oil biodiesel/diethyl ether/diesel by Taguchi method," Fuel, vol. 275, p. 117978, 2020.

17. Jeevanantham, A. K., Reddy, D. M., Goyal, N., Bansal, D., Kumar, G., Kumar, A., Nanthagopal, K., Ashok, B., "Experimental study on the effect of cetane improver with turpentine oil on CI engine characteristics," FUEL, vol. 262, 2020.

18. Pan, M., Huang, R., Liao, J., Ouyang, T., Zheng, Z., Lv, D., Huang, H., "Effect of EGR dilution on combustion, performance and emission characteristics of a diesel engine fueled with n-pentanol and 2-ethylhexyl nitrate additive," Energy Convers. Manag., vol. 176, pp. 246-255, 2018.

19. Imdadul, H. K., Masjuki, H. H., Kalam, M. A., Zulkifli, N. W. M., Alabdulkarem, A., Rashed, M. M., Ashraful, A. M., "Influences of ignition improver additive on ternary (dieselbiodiesel-higher alcohol) blends thermal stability and diesel engine performance,"
Energy Convers. Manag., vol. 123, pp. 252264, 2016.

20. Chen, G., Di, L., Zhang, Q., Zheng, Z., Zhang, W., "Effects of 2,5-dimethylfuran fuel properties coupling with EGR (exhaust gas recirculation) on combustion and emission characteristics in common-rail diesel engines," Energy, vol. 93, no. 1, pp. 284-293, 2015.

21. Qian, W., Huang, H., Pan, M., Huang, R., Tong, C., Guo, X., Yin, J., "Effects of 2ethylhexyl nitrate and post-injection strategy on combustion and emission characterizes in a dimethyl carbonate/diesel blending engine," FUEL, vol. 263, 2020.

22. Ickes, A.M., Bohac, S.V., Assanis, D.N., "Effect of 2-Ethylhexyl Nitrate Cetane Improver on NOx Emissions from Premixed Low-Temperature Diesel Combustion," Energy \&Fuels, vol. 23, no. 10, pp. 4943-4948, 2009.

23. Serena, F.S., Nicolau, E., Favreau, G., Jouanneau, Y., Marchal, R., "Biodegradability of 2-ethylhexyl nitrate (2-EHN), a cetane improver of diesel oil," Biodegradation, vol. 20, pp. 85-94, 2009.

24. Chen, X., Mark, E., Fuller, C., Goldsmith, F., "Decomposition kinetics for HONO and HNO2," React. Chem. Eng., vol. 4, no. 2, pp. 323-333, 2019.

25. Li, X., Qin, S., Huang, X., Liu, H., "Multi-component effect and reaction mechanism for low-temperature ignition of kerosene with composite enhancer," Combust. Flame 2019, pp. 401-410, 2019.

26. Pan, M., Qian, W., Huang, R., Tong, C., Huang, H., Xu, L., Hao, B., "Effects of dimethyl carbonate and 2-ethylhexyl nitrate on energy distribution, combustion and emissions in a diesel engine under different load conditions," Energy Convers. Manag., vol. 199, 2019.

27. Kuszewski, H., "Effect of adding 2ethylhexyl nitrate cetane improver on the autoignition properties of ethanol-diesel fuel blend - Investigation at various ambient gas temperatures," Fuel, vol. 224, pp. 57-67, 2018. 28. Imdadul, H. K., Masjuki, H. H., Kalam, M. A., Zulkifli, N. W. M., Kamruzzaman, M., Shahin, M. M., Rashed, M. M., "Evaluation of oxygenated n-butanol-biodiesel blends along with ethyl hexyl nitrate as cetane improver on diesel engine attributes," J. Clean. Prod., vol. 141, pp. 928-939, 2017.

29. Kumar, H., Sarma, A. K., Kumar, P., “A 
novel approach to study the effect of cetane improver on performance, combustion and emission characteristics of a CI engine fuelled with E20 (diesel - bioethanol) blend," Sustain. Chem. Pharm., vol. 14, 2019.

30. Han, Z., Li, B., Tian, W., Xia, Q., Leng, S., "Influence of coupling action of oxygenated fuel and gas circuit oxygen on hydrocarbons formation in diesel engine," Energy, vol. 173, pp. 196-206, 2019.

31. Gülder, Ö. L., Glavincevski, B., "Ignition quality determination of diesel fuels from hydrogen type distribution of hydrocarbons," Combustion and Flame., vol. 63, no 1-2, pp. 231-238, 1986.

32. Cataluna, R. and da Silva, R., "Effect of Cetane Number on Specific Fuel Consumption and Particulate Matter and Unburned Hydrocarbon Emissions from Diesel Engines," Journal of Combustion, 2012.

33. Obeid, F., Van, T.C., Horchler, E.J., Guo, Y., Verma, P., Milijevic, B., Brown, R.J., Ristovski, Z., Bodisco, T.A., Rainey, T., "Engine performance and emissions of high nitrogen-containing fuels", Fuel, vol. 264, 2020. 34. Simsek, S. and Uslu, S., " Experimental study of the performance and emissions characteristics of fusel oil/gasoline blends in spark ignited engine using response surface methodology", Fuel, vol. 277, pp. 118182, 2020.

35. Nautiyal, P., Subramanian, K.A., Dastidar, M.G., Kumar,A., "Experimental assessment of performance, combustion and emissions of a compression ignition engine fuelled with Spirulina platensis biodiesel", Energy, vol. 193, pp. 116861, 2020.

36. Şen, M., Emiroğlu, A. O., Keskin, A., "Production of Biodiesel from Broiler Chicken Rendering Fat and Investigation of Its Effects on Combustion, Performance, and Emissions of a Diesel Engine", Energy \& Fuels, vol. 32, no 4, pp. 5209-5217, 2018.

37. Rizwanul Fattah, I. M., Masjuki, H. H., Kalam, M. A., Wakil, M. A., Rashedul, H. K., Abedin, M. J., "Performance and emission characteristics of a CI engine fueled with Cocos nucifera and Jatropha curcas B20 blends accompanying antioxidants", Industrial Crops \& Products, vol. 57, pp. 132-140, 2014. 